\title{
THE ITEMS OF ARMAMENT AND HORSE HARNESS OF EARLY SCYTHIAN CULTURE, FOUND NEAR THE ALEKSEEVSKY HAMLET OF THE STAVROPOL REGION
}

\author{
Yuriy A. Prokopenko \\ North-Caucasus Federal University, Stavropol, Russian Federation
}

\begin{abstract}
The paper studies the items of armament and horse harness, discovered in 1940 near the Alekseevsky hamlet (Stavropol plateau) and published by T.M. Minaeva in 1956 ( 8 items). For the first time the entire archaeological complex (25 items) has been subjected to chronological and morphological analysis. The items include large rhombic arrowheads, bronze rings with a movable clutch, bronze horse bits with stape ends, bronze cheek-pieces with three cylinder-couplings in the rod, cylindrical strings of beads and metal platelets. Cross chronological analysis of materials from the Alekseevsky hamlet, from known complexes of the $8^{\text {th }}-7^{\text {th }} \mathrm{cc}$. BC from North Caucasus, Ukraine and Asia Minor allowed the author to refer the studied items to the village of Zhabotin $\left(1^{\text {st }}\right.$ half of the $7^{\text {th }}$ century BC). In the process of examining the abovementioned items, some of the features that characterize their production technology have been identified. For example, arrowheads were cast in unilateral forms (arrowhead no. 6 demonstrates process scraps - double V-shaped tenon, absence of mirror conformity of halves, cast in unilateral forms). The edges of arrowheads' blades were forged at the top on both sides. The soldering technology was used in the creation of these items along with the casting technology. Comparative analysis of materials from the Alekseevsky hamlet and the like makes it possible to propose a preliminary relative chronology of Zhabotin village monuments. The earliest monuments (beginning - the first quarter of the $7^{\text {th }}$ century $\mathrm{BC}$ ) are represented with the complex from the Uashkhitu barrow, items from the burial located on the Chishkho hill, complex from the Endzha barrow; then the items from the Alekseevsky hamlet and inventory from barrow 524 near the Zhabotin village; then the complexes from barrow 1 and barrow 2 of the Khadzhokh burial mound; then the materials from barrow 9 of the burial mound near the hamlet of Krasnoe znamya (end of the second quarter - third quarter of the $7^{\text {th }}$ century BC).

Key words: Central Caucasus, Early Scythian period, Zhabotin village, horse harness, arrows, cast products.

Citation. Prokopenko Yu.A. The Items of Armament and Horse Harness of Early Scythian Culture, Found near the Alekseevsky Hamlet of the Stavropol Region. Vestnik Volgogradskogo gosudarstvennogo universiteta. Seriya 4, Istoriya. Regionovedenie. Mezhdunarodnye otnosheniya [Science Journal of Volgograd State University. History. Area Studies. International Relations], 2018, vol. 23, no. 2, pp. 17-31. (in Russian). DOI: https://doi.org/ 10.15688/jvolsu4.2018.2.2
\end{abstract}

\section{КОМПЛЕКС ПРЕДМЕТОВ ВООРУЖЕНИЯ И КОНСКОЙ УПРЯЖИ РАННЕСКИФСКОЙ КУЛЬТУРЫ, ОБНАРУЖЕННЫЙ У ХУТОРА АЛЕКСЕЕВСКИЙ СТАВРОПОЛЬСКОГО КРАЯ \\ Юрий Анатольевич Прокопенко \\ Северо-Кавказский федеральный университет, г. Ставрополь, Российская Федерация}

Аннотация. В статье рассматриваются предметы вооружения и конской упряжи, обнаруженные в 1940 г. у хут. Алексеевский (Ставропольское плато), опубликованные Т.М. Минаевой в 1956 г. (8 предметов). Впервые хронологическому и морфологическому анализу подвергнут весь археологический комплекс (25 предметов): 
крупные ромбические наконечники стрел, бронзовые кольца с подвижной муфтой, бронзовые конские удила с окончаниями в виде стремечка, бронзовые псалии с тремя цилиндрами-муфтами в стержне, цилиндрические пронизи и бляшки. Перекрестный хронологический анализ материалов из хут. Алексеевского и известных комплексов VIII-VII вв. до н.э. Северного Кавказа, Украины и Малой Азии позволил автору отнести вещи из хут. Алексеевского к горизонту «Жаботин» - первой половине VII в. до н. э. В процессе осмотра перечисленных предметов были выявлены некоторые особенности, характеризующие технологию их производства. Наконечники стрел отливались в односторонних формах (у наконечника № 6 наблюдается технологический брак двойной V-образный шип - отсутствие зеркального совпадения половин, отлитых в односторонних формах). Края лопастей наконечников в верхней части прокованы с обеих сторон. Кроме литья в процессе создания данных изделий использовалась технология пайки (следы пайки на бляхах). Сравнительный анализ материалов из хут. Алексеевского и ему подобных позволяет предложить предварительную относительную хронологию памятников горизонта «Жаботин». Наиболее ранними (начало - первая четверть VII в. до н. э.) являются: комплекс из кургана Уашхиту, вещи из погребения на возвышенности Чишхо, комплекс из кургана Енджа; затем следуют предметы из хут. Алексеевского и инвентарь кургана 524 у селения Жаботин; далее - комплексы из курганов № 1 и 2 могильника Хаджох; затем материалы из кургана 9 могильника у хут. Красное Знамя (конец второй четверти - третья четверть VII века до н. э.).

Ключевые слова: Центральное Предкавказье, раннескифский период, горизонт «Жаботин», конская упряжь, стрелы, литые изделия.

Цитирование. Прокопенко Ю. А. Комплекс предметов вооружения и конской упряжи раннескифской культуры, обнаруженный у хутора Алексеевский Ставропольского края // Вестник Волгоградского государственного университета. Серия 4, История. Регионоведение. Международные отношения. - 2018. - Т. 23 , № 2. -C. 17-31. - DOI: https://doi.org/10.15688/jvolsu4.2018.2.2

В последние годы наблюдается особое внимание исследователей к открытым в Предкавказье комплексам предскифского времени IX - первой половины VII в. до н.э., то есть черногоровского и новочеркасского периодов (по А.И. Тереножкину) или периодов НаB2 НаB3 (по центральноевропейской системе хронологии). Это объясняется дискуссионностью вопроса, связанного с уточнением позднего этапа существования киммерийской культуры и соответственно - начала скифской архаики, а также проблемой хронологии функционирования в регионе центров металлобработки. В опубликованных сводках в большей степени рассматриваются предметы из памятников Прикубанья, района Кисловодской котловины, предгорных и горных районов Центрального Предкавказья. При этом фактически не затронуты комплексы и отдельные находки предскифского времени, обнаруженные в районе Ставропольской возвышенности.

В многочисленных публикациях в списке материалов переходного периода от предскифского к раннескифской архаике Ставропольское плато представляет комплекс бронзовых предметов вооружения и конской упряжи, выявленный близ хут. Алексеевского (окрестности с. Курсавка - 120 км юго-восточнее г. Ставрополя). Согласно музейному акту приема пред- метов это: «Металлические вещи, найденные на хут. Алексеевском вблизи села Казинки Орджоникидзевского края (в предвоенные годы Ставрополье в него входило. - Ю. П.). Двенадцать наконечников стрел, два удила, стремена, четыре крышечки украшения для лошадиных ног и другие металлические вещи, все нашиты на картон. Дата поступления 1940 г.».

Комплекс был опубликован Т.М. Минаевой в 1956 г. [17, с. 338]. Исследователь отметила в числе находок 12 бронзовых двулопастных наконечников стрел, 4 муфтовых псалия, стремечковидные удила и др. - всего 29 предметов. Из них в публикации были размещены изображения восьми предметов: 2 наконечника стрел жаботинского типа (один с шипом), муфтовый псалий, кольцо с подвижной муфтой, столбик для перекрестных ремней, дисковидная бляшка с полукруглой петлей, стремечковидные удила, ворворка неправильной усеченно-конической формы [17, рис. 2]. За последние 30 лет перечисленные рисунки в комплексе и по отдельности неоднократно переопубликовывались $[6$, с. 139, рис. 53,$9 ; 8$, с. 176 , рис. $85 ; 9$, с. 21,$23 ; 13$, с. 44 , рис. $14,1-10 ; 20$, рис. VI.2, $21 ; 23$, с. 206 , рис. 1,$8 ; 25$, рис. 38,41 ; и др.].

Следует отметить, что исследователи, привлекавшие в своих публикациях указанные изображения предметов, судя по отсутствию 
сведений в отделе археологии СГМЗ о их работе с коллекцией из хут. Алексеевского ${ }^{1}$, не подвергали их сомнению, видимо, ориентируясь на авторитет известного археолога Т.М. Минаевой. Я решил сравнить ее иллюстрации с реальными предметами из комплекса из хут. Алексеевского. В результате стало ясно, что большая часть опубликованных изображений значительно отличается от оригиналов или, в отдельных случаях, они просто неверны. Наблюдается значительное упрощение трактовки нарисованных предметов, при котором не фиксируется ряд важных деталей.

Действительно, Татьяна Максимовна известна своими качественными рисунками артефактов, иллюстрирующими ее статьи и монографии. Однако не всегда она являлась автором изображений. В отдельных случаях предметы зарисовывались по просьбе T.М. Минаевой другими сотрудниками музея ${ }^{2}$. Скорее всего, в данном случае мы столкнулись с этим вариантом.

Плохое качество изображений в статье T.М. Минаевой и обстоятельство их малого количества (8 предметов из 25) позволяет мне еще раз обратиться к публикации комплекса предметов вооружения и конской упряжи из хут. Алексеевского.

Согласно сведениям, зафиксированным в «Книге поступления археологической коллекции из Музея Северного Кавказа» предметы, обнаруженные у «хут. Алексеевского близ с. Казинка Орджоникидзевского края» (в настоящее время Ставропольского), поступили в музей в 1940 г. (Книга поступления археологической коллекции из Музея Северного Кавказа - 9139/238 - 4462). В целом коллекция насчитывает 25 вещей, относящихся к колчанному набору и конской упряжи.

В состав комплекса входит 7 наконечников стрел (один фрагментирован).

1) Наконечник с вытянутым ромбическим пером и укороченной втулкой с шипом о.ф. 3586/1 (рис. 1, 1). Размеры ${ }^{3}$ : Дл- 43 мм; Д втулки -6; наибольшая Ш лопастей - 14 мм. Рельефная имитация втулки проходит через все перо. В нижней части наконечника - каверна овальной формы (Д $1 \times 2$ мм). По всей длине имитации втулки проходит ребро.

2) Наконечник с вытянутым ромбическим пером и удлиненной втулкой с шипом - о.ф. 3586/2 (рис. 1, 2). Размеры: Дл - 48 мм; Д втулки - 55 мм; наибольшая Ш лопастей 13 мм. Рельефная имитация втулки проходит почти через все перо. Почти по всей длине имитации втулки (2/3) проходит ребро.

3) Наконечник с ромбическим пером и укороченной втулкой с шипом - о.ф. 3586/3 (рис. 1, 3). Размеры: Дл - 40 мм; Д втулки - 6; наибольшая Ш лопастей - 10 мм. Рельефная имитация втулки проходит через все перо. В нижней части наконечника (в месте перехода втулки в перо) отверстие (Д 2,5 $\times 3$ мм). По всей длине имитации втулки (до отверстия) проходит ребро. Шип обломан, отходит от втулки на 2 мм.

4) Наконечник с вытянутым ромбическим пером и укороченной втулкой с шипом о.ф. 3586/4 (рис. 1, 4). Размеры: Дл - 45 мм; Д втулки - 7; наибольшая Ш лопастей - 13 мм. Рельефная имитация втулки проходит через все перо. В нижней части наконечника - каверна вытянутой овальной формы (Д $1,5 \times 2 \times 8$ мм). По всей длине имитации втулки (до каверны) проходит ребро.

5) Наконечник фрагментированный. Сохранилась укороченная втулка с шипом о.ф. 3586/5 (рис. 1, 5). Размеры сохранившейся части: Дл - 12 мм; Д втулки - 6. Шип (Дл 7 мм) расположен вплотную к втулке - на расстоянии 1 мм.

6) Наконечник с ромбическим пером и укороченной втулкой с шипом - о.ф. 3586/6 (рис. 1, б). Размеры: Дл - 42 мм; Д втулки - 6; наибольшая Ш лопастей - 14 мм. Рельефная имитация втулки проходит через всеперо. В центральной части наконечника - каверна прямоугольной формы (Д $3 \times 6$ мм). На краю лопасти со стороны шипа имеется выемка (размеры: $3 \times 4$ мм). На противоположной лопасти фиксируется округлое отверстие (Д -2 мм). По всей длине имитации втулки проходит ребро. Шип двойной, широко отведен от втулки.

7) Наконечник с ромбическим пером и укороченной втулкой с шипом - о.ф. 3586/7 (рис. 1, 7). Размеры: Дл - 41 мм; Д втулки 7; наибольшая Ш лопастей - 14 мм. Рельефная имитация втулки проходит через все перо. В нижней части наконечника (в месте перехода втулки в перо) - отверстие овальной формы (Д $2 \times 4$ мм). По всей длине имитации втулки проходит ребро. Шип обломан, отходит от втулки на 2,5 мм. 


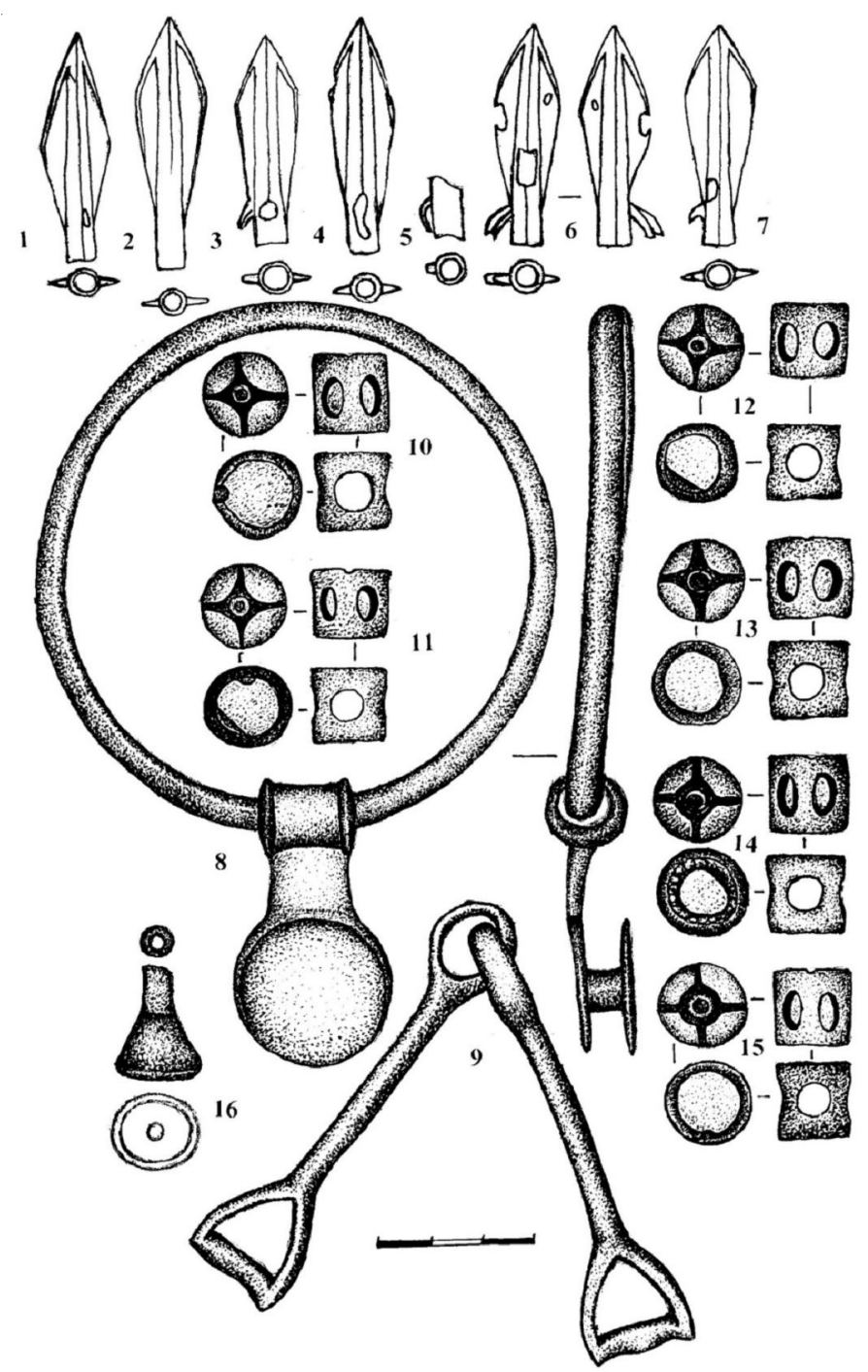

Рис. 1. Предметы вооружения и конской упряжи, обнаруженные у хут. Алексеевский: $1-7$ - наконечники стрел; 8 - кольцо с подвижной муфтой; 9 - удила; 10-15 - пронизи; 16 - ворворка. Все - бронза

Fig. 1. Bronze items of armament and horse harness, found near the Alekseevsky hamlet:

1-7 - arrowheads; 8 - ring with a movable clutch; 9 - bits; 10-15 - strings of beads; 16 - vorvorka

В состав комплекса входят литые двусоставные стремечковидные удила с гладкими стержнями-грызлами - о.ф. 3586/23 (рис. 1, 9). Концевое «стремечко» удила № 1 имеет подтреугольную форму; один край вилки слегка выступает за овальную в сечении перекладину-подножку. У концевого «стремечка» удила № 2 оба края вилки слегка выступают за овальную в сечении подножку, которая в центральной части (на внешней поверхности) имеет незначительную выпуклость (форма «стремечка» - между подтреугольной и D-образной). Размеры: Дл удила № $1-88$ мм; Дл удила № 2 - 89; Д стержня (грызла) удила № 1 - 7; Д стержня (грызла) удила № 2 - 7; Ш «стремечка» № 1 - 21; Ш «стре- мечка» № 2 - 22; Д перекладин «стремечка»: № $1-4 \times 5$, № $2-4 \times 5$; Д кольца удила № $1-$ $18 \times 19$; Д кольца удила № $2-19 \times 20$; Ш кольца № $1-5$; Ш кольца № $2-6$ мм.

Конский убор, кроме удил, представляют четыре литых С-видных трехдырчатых псалия (псалии слегка изогнуты концами в одну сторону) (рис. 2, 2, 3; 3, 1, 2). Отверстия оформлены в виде трех поперечных цилиндров в стержне - муфт. Один конец псалий завершается навершием усеченно-биконической формы; противоположный выполнен в виде рельефно оформленного копыта лошади (в профиль - подтреугольной формы). Внутренняя сторона копыт декорирована рельефным V-образным знаком. 


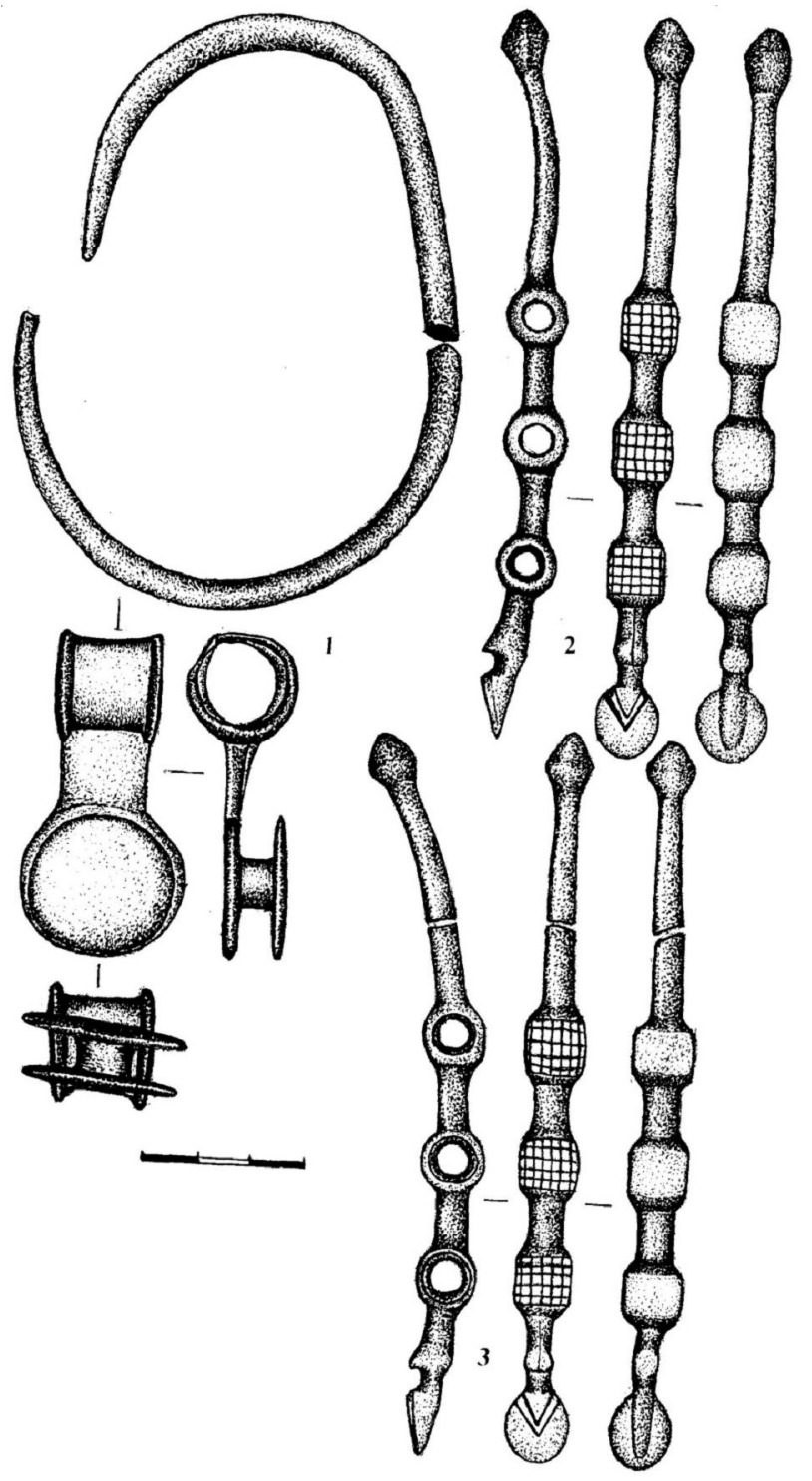

Рис. 2. Предметы конской упряжи, обнаруженные у хут. Алексеевский:

1 - кольцо с подвижной муфтой; 2-3 - псалии. Все - бронза

Fig. 2. Bronze items of horse harness, found near the Alekseevsky hamlet:

1 - ring with a movable clutch; $2-3$ - cheek-pieces

1) Псалий муфтовый - о.ф. 3586/9 (рис. 2 , 2). Размеры: Дл - 135 мм; Д стержня в районе муфт - 7; Д стержня на утончающихся концах $-4-5$; Д отверстий -7 ; Д муфт -11 ; Д копыта $-12 \times 14$; расстояние между муфтами $-12-13$; расстояние от края копыта до выступа (путового сустава) - 16; Д навершия - 8; В навершия - 11 мм.

С внутренней стороны муфты декорированы рельефными прямоугольными выступами - 6 рядов по 6 прямоугольников в каждом $(1,5 \times 1,5$ мм). Дл концов V-образного знака -8 ; Ш концов V-образного знака -3 ;
Ш угла V-образного знака - 1,5; В V-образного знака над уровнем копыта 1 мм.

2) Псалий муфтовый - о.ф. 3586/10 (рис. 2, 3). Размеры: Дл - 135 мм; Д стержня в районе муфт - 6; Д стержня на утончающихся концах - 4-5; Д отверстий - 7; Д муфт 11; Д копыта - $12 \times 12,5$; расстояние между муфтами - 12 - 13; расстояние от края копыта до выступа (путового сустава) - 17; Д навершия - 8; В навершия - 9 мм.

С внутренней стороны муфты декорированы рельефными прямоугольными выступами - 5 рядов по 6 прямоугольников в каждом 


\section{АРХЕОЛОГИЯ}

$(1,5 \times 1,5$ мм). Дл концов V-образного знака 8; Ш концов V-образного знака - 3; Ш угла V-образного знака - 1,5; B V-образного знака над уровнем копыта 1 мм.

3) Псалий муфтовый - о.ф. 3586/11 (верхняя часть стержня отколота) (рис. 3,1 ). Размеры: Дл - 131 мм; Д стержня в районе муфт 6 ; Д стержня на утончающихся концах $-4-5$; Д отверстий $-8,8,7$; Д муфт - 11; Д копыта $11,5 \times 12$; расстояние между муфтами -12 13; расстояние от края копыта до выступа (путового сустава) - 17; Д навершия - 5; В навершия -6 мм.

С внутренней стороны муфты декорированы рельефными прямоугольными выступа- ми - 4-5 рядов по 6 прямоугольников в каждом $(1,5 \times 1,5$ мм). У центральной муфты левая часть поверхности не имеет продольных насечек. Дл концов V-образного знака - 8; Ш концов V-образного знака - 3; Ш угла $\mathrm{V}$-образного знака - 1,5; В V-образного знака над уровнем копыта 1 мм.

4) Псалий муфтовый - о.ф. 3586/12 (рис. 3, 2). Размеры: Дл - 134 мм; Д стержня в районе муфт - 6; Д стержня на утончающихся концах -4 ; Д отверстий - 7; Д муфт 11 ; Д копыта - $11 \times 14$; расстояние между муфтами - 11-12; расстояние от края копыта до выступа (путового сустава) - 17; Д навершия -9 ; В навершия -9 мм.

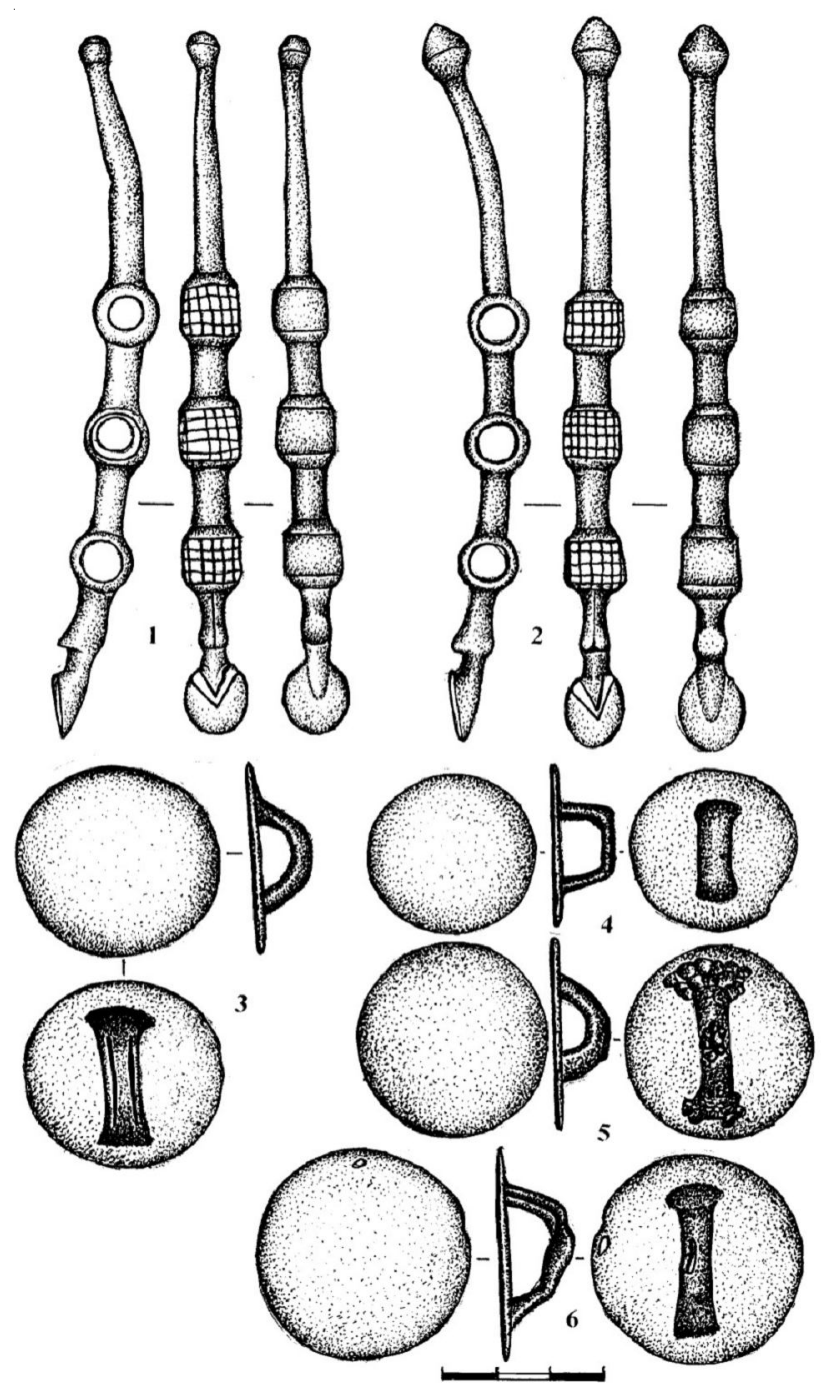

Рис. 3. Предметы конской упряжи, обнаруженные у хут. Алексеевский: 1-2 - псалии; 3-6 - бляшки. Все - бронза

Fig. 3. Bronze items of horse harness, found near the Alekseevsky hamlet:

1-2 - cheek-pieces; 3-6 - platelets 
С внутренней стороны муфты декорированы рельефными прямоугольными выступами - 4 ряда по 5-6 прямоугольников в каждом $(1,5 \times 1,5$ мм). Дл концов V-образного знака - 7; Ш концов V-образного знака - 3; Ш угла V-образного знака - 1,5; В V-образного знака над уровнем копыта 1 мм.

К предметам конского убора (упряжь колесниц) относятся два литых кольца с подвижной муфтой (одно фрагментировано):

1) Цельный комплект - кольцо из округлого в сечении прута вдето в муфту с привеской - о.ф. 3586/24 (рис. 1, 8). Диаметр муфты, превышающий диаметр прута, делает ее подвижной, то есть свободно перемещающейся по кольцу. Муфта соединяется слегка изогнутой подпрямоугольной пластиной с катушкообразной привеской (два диска, соединенных цилиндрической перемычкой). Размеры: Д овального кольца $100 \times 110$ мм; Д прута кольца - 5-6; Дл муфты - 18; Д муфты $-1,4 \times 1,5$; Т стенок муфты - 2-4; Дл муфты с привеской - 54; Д дисков катушкообразной привески - 30 и 28 ; Д цилиндрической перемычки - 7; Т дисков -2 (в центре), 1 мм (по краям).

2) Фрагментированный комплект (3 детали кольца с подвижной муфтой) - деформированное (овальное) кольцо из округлого в сечении прута расколото на две половины о.ф. 3586/25 (рис. 2, 1). Деталь № 3 - муфта с привеской - о.ф. 3586/26. Муфта, аналогичная выше отмеченной, соединяется подпрямоугольной пластиной с катушкообразной привеской (два диска, соединенных цилиндрической перемычкой, расположены под углом по отношению к оси муфты). Размеры: Д овального кольца $-83 \times 103$ мм; Д прута кольца - 3-6; Дл муфты - 18; Д муфты $20 \times 21$; Т стенок муфты $-3-1,5$; Дл муфты с привеской - 60; Д дисков катушкообразной привески - 27 и 25 ; Д цилиндрической перемычки - 8; Т дисков - 3 и 2 (в центре), 1,5 и 1 мм (по краям).

Также в комплекс конской упряжи входят 6 бронзовых литых цилиндрических пронизей:

1) Пронизь в форме полого цилиндра о.ф. - 3586/13 (рис. 1, 10). Размеры: Д - 15; В - 14; Т стенки - 2 мм. Предмет имеет четыре боковых округлых отверстия (Д - 7 мм).
Лицевая сторона щитка цилиндра декорирована четырехлучевой розеткой.

2) Пронизь в форме полого цилиндра о.ф. - 3586/14 (рис. 1, 11). Размеры: Д - 16; В - 14; Т стенки - 2-3 мм. Предмет имеет четыре боковых округлых отверстия (Д - 68 мм). Лицевая сторона щитка цилиндра декорирована четырехлучевой розеткой.

3) Пронизь в форме полого цилиндра о.ф. -3586/15 (рис. 1, 12). Размеры: Д - 16; В - 14; Т стенки - 2-4 мм. Предмет имеет четыре боковых округлых отверстия (Д 8 мм). Лицевая сторона щитка цилиндра декорирована четырехлучевой розеткой.

4) Пронизь в форме полого цилиндра о.ф. - 3586/16 (рис. 1, 13). Размеры: Д - 16; В - 14; Т стенки - 2-3 мм. Предмет имеет четыре боковых округлых отверстия (Д - 78 мм). Лицевая сторона щитка цилиндра декорирована четырехлучевой розеткой.

5) Пронизь в форме полого цилиндра о.ф. - 3586/17 (рис. 1, 14). Размеры: Д - 16; В - 14; Т стенки - 2,5-4 мм. Предмет имеет четыре боковых округлых отверстия (Д 8 мм). Лицевая сторона щитка цилиндра декорирована четырехлучевой розеткой.

6) Пронизь в форме полого цилиндра о.ф. $-3586 / 18$ (рис. 1, 15). Размеры: Д - 16; В - 13; Т стенки - 3-3,5 мм. Предмет имеет четыре боковых округлых отверстия (Д - 78 мм). Лицевая сторона щитка цилиндра декорирована четырехлучевой розеткой.

В числе предметов из хут. Алексеевского следует отметить бронзовую литую ворворку усеченно-конической (воронковидной) формы - о.ф. 3586/8 (рис. 1, 16). Размеры: Д расширенной части - 16; Д зауженной части -5 ; В -22 ; В конической части - 12 мм.

Завершают список предметов комплекса 4 бронзовые литые бляхи:

1) Бляха, представляющая собой круглый диск с полукруглой (припаянной) петлей на оборотной стороне - о.ф. 3586/19 (рис. 3, 3). Размеры: Д-37; Т диска-2; Ш петли - 7; Т петли - 4; В петли - 10 мм.

2) Бляха, представляющая собой круглый диск с П-образной (припаянной) петлей на оборотной стороне - о.ф. 3586/20 (рис. 3, 4). Размеры: Д-31; Т диска-2; Ш петли -6; Т петли - 2,5-3; В петли - 11 мм. 
3) Бляха, представляющая собой овальный диск с полукруглой (припаянной) петлей на оборотной стороне - о.ф. 3586/21 (рис. 3, 5). Размеры: Д - $32 \times 35$; Т диска - 1,5; Ш петли 5; Т петли - 5; В петли - 12 мм. На оборотной стороне диска, в местах присоединения концов петли к диску, фиксируются следы пайки.

4) Бляха, представляющая собой овальный диск с полукруглой (припаянной) петлей на оборотной стороне - о.ф. 3586/22 (рис. 3, б). Размеры: Д - 39; Т диска - 1,5; Ш петли 6; Т петли - 3-4; В петли - 8-12 мм. На краю диска имеется отверстие - каверна овальной формы (Д - 1,5 × 1 мм). На внешней поверхности петли фиксируется незначительная выемка (каверна) вытянутой овальной формы (Д $-1 \times 1,5 \times 7$ мм $)$.

В процессе осмотра перечисленных предметов были выявлены некоторые особенности, характеризующие технологию их производства.

Bce предметы литые. Наконечники стрел, видимо, отливались в односторонних формах. Об этом свидетельствует наконечник № 6. Данный экземпляр выполнен с браком - двойным шипом (рис. 1, б). Так могло получиться только в случае отсутствия зеркального совпадения половин, отлитых в односторонних формах. В результате их спайки половинки шипов (выпуклые снаружи, плоские с внутренней стороны) не наложились друг на друга, а раздвоили шип, сделав его V-образным, поскольку одна половинка шипа расположена ближе к втулке, чем другая. Края лопастей наконечников в верхней части прокованы с обеих сторон.

Кроме литья, в процессе создания данных изделий использовалась технология пайки. В частности, у круглых блях петли припаяны (прослеживаются следы пайки).

Также интересны сведения, касающиеся декорирования муфтовых псалий. Орнаментирование внутренней стороны муфт поперечными выемками характерно для жаботинского этапа. Например, такой вариант рифления поверхности муфт зафиксирован на псалиях из кургана 2 могильника Хаджох [22, с. 4267]. Однако алексеевские экземпляры декорированы рядами прямоугольников. Первая стадия их оформления - нанесение поперечных бороздок (как и у хаджохских псалий).
Затем наносились продольные насечки. Они выполнялись вручную миниатюрным зубилом. Об этом свидетельствует неравномерность ширины рядов. Это же подтверждает декор центральной муфты экземпляра № 3 (о.ф. 3586/11) (рис. 3,1 ). Поверхность ее правой части имеет насечки как поперечные, так и продольные, а в левой части нанесены только поперечные бороздки. Видимо, по каким-то причинам мастер не доделал работу.

Как уже было отмечено, 8 рисунков предметов из алексеевского комплекса неоднократно переиздавались. Однако в настоящее время нет единства ни в хронологии подобных комплексов (от рубежа IX-VIII вв. до н. э., по А. Иванчику [8, с. 36, 178], середины - второй половины VIII в. до н. э., по T.В. Рябковой [20, с. 411], до конца VIII - первой четверти VII в. до н. э., по С.А. Скорому [24, с. 61-65] или первой половины VII в. до н. э., по В. Эрлиху $[29$, с. $178 ; 30$, с. 453] и С.Б. Вальчаку [3, с. 34-39, 72, 89-94]), ни в типологии предметов. Например, алексеевский муфтовый псалий С.Л. Дударев, видимо, обманутый неверным его изображением, отнес к варианту 3 вида III типа II отдела II (типу «Камышеваха» по А.И. Тереножкину), а близкие по форме экземпляры жаботинского типа к варианту 1 вида II $[6$, с. $138-139$, рис. 52; 53]. Следует отметить другой, более удачный, вариант типологии, предложенный В.Р. Эрлихом и поддержанный А.Ю. Скаковым. Согласно данной версии, указанный алексеевский предмет был включен в группу псалиев типа «Уашхиту-Жаботин» (вариант Жаботин) [23, с. 205,208 , рис. 1,8$]$.

Следует отметить характерное для жаботинского этапа (или РСК-І по И.Н. Медведской) совмещение в алексеевском комплексе предметов, употреблявшихся уже в новочеркасское время, и более поздних, известных по раннескифским материалам второй половины VII в. до н. э.

В частности, в состав комплекса входят два бронзовых литых кольца с подвижными муфтами. Согласно устаревшей точке зрения, это подпружные кольца [6, с. 141; 11, с. 112]. В настоящее время большинство исследователей склонно считать такие предметы деталями упряжи колесниц $[1$, с. $12-13 ; 8$, с. $36 ; 15$, с. $42-44 ; 23$, с. $212 ; 27$, с. $59-60$; и др.]. 
Ряд подобных колец с подвижными муфтами представлен в материалах новочеркасского времени VIII - начала VII в. до н. э.: кладов и погребений могильников, открытых на Северном Кавказе. В частности, они выявлены: в погребении 9 Псекупского могильника № 1 (в комплекте с бронзовыми двухкольчатыми удилами с дополнительными звеньями, бронзовыми трехпетельчатыми псалиями, бляшкой), Пшишском кладе (в комплексе с бронзовыми двухкольчатыми удилами с дополнительными звеньями, бронзовыми трехпетельчатыми псалиями с загнутой лопастью и блящками), погребении 1 Чишхо близ аула Тауйхабль (в комплекте с бронзовыми стремечковидными удилами, бронзовыми трехпетельчатыми псалиями с загнутой лопастью, колесничными бронзовыми кольцами с дисками и др.), кургане 46 в урочище «Клады» (в комплексе с бронзовыми двухкольчатыми удилами, бронзовыми трехпетельчатыми псалиями с загнутой лопастью и различного вида бляшками, в том числе лунницей), в кладе из подножия г. Развалка (окрестности г. Железноводска) (в комплекте с бронзовыми двухкольчатыми удилами с дополнительными звеньями, бронзовыми трехпетельчатыми псалиями с загнутой лопастью, бронзовыми кольцами и бляшками) $[6$, рис. $66,76,78$, $101 ; 21$, c. 7-9].

Встречаются они также в новочеркасских памятниках на территории Лесостепи: в погребении у с. Бутенки (в комплексе с бронзовыми двукольчатыми удилами с дополнительными звеньями, бронзовыми трехпетельчатыми псалиями с загнутой лопастью, новочеркасскими наконечниками стрел, бронзовыми кольцами, бляшками и железными наконечниками копий) и в кургане у с. Квитки (в комплекте с бронзовыми двукольчатыми удилами с дополнительными звеньями, бронзовыми трехпетельчатыми псалиями с загнутой лопастью, прорезными бубенцами, бляшками, в том числе лунницей и др.) [8, с. 127 , рис. 58 ; с. 218-219, рис. 106; 10 , с. 45 , рис. 6,12$]$.

Известны такие предметы в новочеркасских комплексах на территории причерноморских степей (Преображенское, Аксай) $[2$, с. $40-56$, рис. $2,2,3 ; 8$, с. 38 , рис. $15,5,6]$.

Однако бронзовые кольца с подвижными муфтами встречаются и в инвентаре более поздних погребений, включающих вещи, характерные для раннескифского времени. Например, в погребении у Лермонтовского разъезда такие кольца сочетались с двухкольчатыми удилами с дополнительными звеньями, трехпетельчатыми псалиями с загнутой лопастью, бляшками и скифским железным акинаком с бабочковидным перекрестьем VII-VI вв. до н. э. [8, с. 44, рис. 20]. В кургане 2 могильника Хаджох аналогичные предметы находились в комплексе с бронзовыми удилами и псалиями скифского типа, комплектом удил из разных звеньев (двухкольчатое и стремечковидное) и изделиями, выполненными в зверином стиле [22, с. $42-67 ; 23$, рис. $3-5]$.

В инвентаре малоазийского погребения из Норшунтепе бронзовое кольцо с фрагментом утерянной муфты сопровождали железные наконечники копий, два железных ножа, железный топор, бронзовые стремечковидные и однокольчатые удила с витыми стержнями, две бронзовые пронизи с головками грифобаранов и др. [8, рис. 4]. Если учесть, что в Закавказье железные топоры появляются в конце VIII в. до н. э., а наибольшего распространения достигают только в VII-VI вв. до н. э. [7, с. 79-85], вряд ли этот комплекс может быть датирован ранее первой половины VII в. до н. э. Тем более, что в данном случае половина вещей выполнена из железа, а треть - в раннескифском стиле. Мне известны только три комплекса конца VIII - начала VII в. до н. э., в которых железные топоры (в двух случаях - секиры) сочетаются с новочеркасскими наконечниками стрел, двукольчатыми удилами, бронзовыми трехпетельчатыми псалиями с загнутой лопастью и другими новочеркасскими предметами - погребение 34 могильника на территории Кисловодской мебельной фабрики, находка на правом берегу р. Баланды (Саратовская область - бассейн р. Дон) и погребение 12 могильника № 2 Татарского городища (южные окрестности г. Ставрополя) $[8$, рис. $62 ; 11$, табл. $\mathrm{XX}, 1 ; 12$, с. $22 ; 26$, с. 149 , рис. 20, 21].

Алексеевские бронзовые стремечковидные удила относятся к варианту 2 типа III отдела I согласно типологии С.Л. Дударева. Автор отметил, что бесспорным указателем наступления поздней грани предскифского периода и перехода к раннескифской эпохе 
являются «подножки» удил с тремя резкими, четкими выступами. При этом исследователь аналогиями алексеевских удил назвал подобные предметы из хут. Дукмасова и погребения 19 кургана 1 Абинского могильника [6, c. 126-127]. Однако у изделий из алексеевского комплекса выступы присутствуют только на конце одного удила (но они слабее обозначены), а на стремечке второго выступ вообще всего один (рис. 1,9). Исходя из этого, более близкими аналогиями им являются удила из кургана 524 у хут. Жаботин (у одного звена на подножке стремечка фиксируются только два выступа) и из кургана 2 могильника Хаджох (звено смешанного комплекта заканчивается стремечком с подножкой, имеющей слабо обозначенные выступы) [9, с. 237; 22, с. 42-67].

Уточняют датировку алексеевского комплекса бронзовые муфтовые псалии типа «Уашхиту-Жаботин». Наиболее ранние подобные предметы, имеющие загнутую расширенную лопасть, что сближает их с новочеркасскими псалиями, происходят из кургана Уашхиту [27, рис. 5]. Здесь они сопутствуют изделиям новочеркасского типа, как и в алексеевском случае, бронзовым кольцам с подвижной муфтой, а также бронзовым двукольчатым удилам с выступами прямоугольной формы на грызлах, бляшкам с четырехлучевой розеткой и без декора и др.

Хронологически более близки к алексеевскому комплексу предметы из кургана 524 у с. Жаботин и курганов № 1 и 2 могильника Хаджох [9, с. 237; 22, с. 42-67; 23, с. 209-211, рис. 3-5]. В первом случае бронзовые муфтовые С-видные псалии с навершием усеченно-биконической формы сочетались с бронзовыми наконечниками с ромбическим пером и шипом на втулке, аналогичными алексеевским, бронзовыми стремечковидными удилами (с концами стремечка, выступающими за подножку и выпуклой снаружи серединой подножки) и изделиями звериного стиля.

Во втором случае наблюдается разнообразие форм, характерное для жаботинского периода. Здесь также присутствуют бронзовые кольца с подвижной муфтой, бронзовые двукольчатые удила, бляхи с четырехлучевой розеткой (как в комплексе кургана Уашхиту), муфтовые псалии с поперечным рифлением муфт, стремечковидные удила (со слегка выступающими концами стремечка за подножку, как и у алексеевских удил) и вещи раннескифского облика, в том числе псалии и предметы, выполненные в зверином стиле.

Следует отметить, что псалии типа «Уашхиту-Жаботин» именно жаботинского варианта (как и алексеевские) встречаются и в комплексах раннескифского времени второй половины VII в. до н.э. в Украинской степи (Яснозорье, кург. 6; Емчиха, кург. 375; кург. 183 на р. Тенетинка; кург. 2, II группы у с. Медвин в Поросье) [23, с. 208]. В частности, S-видный псалий из кургана 6 могильника Яснозорье завершается загнутым расширенным округлым концом (видимо, имитация копыта) c V-образным знаком на внутренней стороне копыта, как и в случае алексеевских псалий [23, с. 206, рис. 1, 3].

В алексеевском комплексе также имеются вещи раннескифского облика. Кроме отмеченных стремечковидных удил, к ним относятся цилиндрические пронизи с четырьмя отверстиями по бокам и четырехлучевой розеткой на щитке. В частности, подобный предмет происходит из конской уздечки (в комплекте с бронзовыми когтевидными пронизями, железными однокольчатыми удилами и костяными трехдырчатыми псалиями) из помещения 18 Кармир-Блура [8, рис. 12, 17$].$ Аналогичные предметы характерны для погребений могильника у хут. Красное Знамя. Такие пронизи входили в уздечный набор 1 из кургана 1 и уздечный набор коня 1 из кургана 3. В последнем случае щитки пронизей были декорированы четырехлучевой розеткой $[19$, с. 77 , табл. $48,31,38,43 ; 59,131,221$, 135]. Курган 1 датируется по бронзовой обойме с изображением Иштар серединой VII в. до н.э. [18, с. 44].

Здесь же в кургане 9 выявлен набор, включающий 4 удлиненно-ромбических и 2 ромбических наконечника стрел (3 - с шипом), аналогичные алексеевским [19, с. $62-$ 63, табл. 55, 264, 265]. Данные наконечники, согласно типологии А.И. Мелюковой, относятся к первому типу, наиболее раннему в ее первой хронологической группе [16, с. 19, рис. 1].

В.Г. Петренко согласна с мнением А.И. Мелюковой о датировании таких удли- 
ненно-ромбических экземпляров (типа «Енджа») началом - серединой VII в. до н.э. Колчанный набор из болгарского кургана Енджа включал 52 бронзовых наконечника. Из них основную часть составляли двухлопастные наконечники удлиненно-ромбических очертаний, подобные алексеевским. В данном случае они сочетались с двухкольчатыми удилами с жесткоскрепленными псалиями. Как считала И.Н. Медведская, замена удил с напускными удилами и цельнолитыми псалиями произошла на рубеже VIII-VII вв. до н. э. [14, c. 61-64]. В.Р. Эрлих справедливо отмечает, что данный тип удил сложился на основе узды новочеркасского типа, о чем свидетельствует как форма псалиев с загнутой лопастью, так и два отверстия на окончаниях удил, восходящие к обычным новочеркасским удилам $[28$, с. 85-86]. В целом, несмотря на близость данного колчанного набора к наконечникам из хут. Алексеевского и из кургана 524 Жаботин, комплекс Енджа (черпаки с выступающей ручкой, ранний железный меч и др.), видимо, несколько более ранний по сравнению с указанными памятниками. Это согласуется с мнением А.И. Иванчика об относительной архаичности предметов из Енджи в сравнении с жаботинским комплексом [8, с. 198].

Следует отметить важное наблюдение В.Г. Петренко, касающееся корреляции удлиненно-ромбических наконечников из Алексеевского и кургана 9 могильника у хут. Красное знамя. Указывая на меньшие размеры краснознаменских экземпляров по сравнению с алексеевскими, наконечники из кургана 9 автор считает относительно более поздними, чем из алексеевского комплекса $[19$, с. 64].

Свыше пяти десятков бронзовых наконечников стрел жаботинского и келермесского типов было выявлено при раскопках Боказкея в Малой Азии. По приблизительным подсчетам Л.К. Галаниной, не менее 28 их происходит из двух фригийских слоев этого города, восходящих ко второй четверти - середине VII в. до н. э. [5, с. 110]. Еще один комплекс (250 экз.), включающий несколько наконечников жаботинского типа, выявлен у Имирлера (долина между Ташова и Лядиком к северу от Амасьи). А.И. Иванчик обратил внимание на наличие на нескольких экземплярах рельефных знаков типа «следа птичьей лапы».
Подобные метки известны на отмеченных выше наконечниках скифского типа из Боказкея. На этом основании автор отнес данные наконечники к начальному периоду келермесского этапа раннескифской культуры, несколько раньше, чем время возведения Келермесских курганов Веселовского [8, с. 49, рис. 23]. С.Б. Вальчак эти экземпляры со знаками из Ташова - Лядика и Боказкея датировал временем не ранее конца первой четверти - середины VII в. до н. э. [4, с. 35, рис. 4, 10-12].

По мнению Л.К. Галаниной, колчанный набор из указанного кургана 9 у хут. Красное Знамя в сочетании с бронзовыми двухкольчатыми удилами и другими архаическими предметами говорит о принадлежности этого древнейшего краснознаменского комплекса ко второй четверти VII в. до н.э. [5, с. 106].

Таким образом, нужно подчеркнуть, что время создания алексеевского комплекса не может быть ранее начала VII в. до н.э. Сравнительный анализ материалов из хут. Алексеевского и ему подобных позволяет предложить предварительную относительную хронологию памятников горизонта «Жаботин». Наиболее ранними (начало - первая четверть VII в. до н. э.) являются: комплекс из кургана Уашхиту (основная часть предметов типа новочеркасского клада, муфтовые псалии с загнутой лопастью), вещи из погребения на возвышенности Чишхо (большая часть предметов типа новочеркасского клада и удила с жесткоскрепленными псалиями), комплекс из кургана Енджа (наконечники с вытянуто-ромбической формой головки, удила с жесткоскрепленными псалиями); затем следуют предметы из хут. Алексеевского и инвентарь кургана 524 у с. Жаботин; далее - комплексы из курганов № 1 и 2 могильника Хаджох; затем материалы из кургана 9 могильника у хут. Красное Знамя (конец второй четверти - третья четверть VII в. до н. э.).

\section{ПРИМЕЧАНИЯ}

${ }^{1}$ Комплекс предметов из хут. Алексеевского хранится в фондах Ставропольского государственного историко-культурного и природно-ландшафтного музея-заповедника им. Г.Н. Прозрителева, Г.К. Праве. Приношу искреннюю признательность коллективу отдела археологии СГМЗ и лично ди- 
ректору Музея Н.А. Охонько за оказанное содействие в процессе изучения материалов коллекции из хут. Алексеевского, и предоставленную возможность их публикации.

2 Выражаю искреннюю признательность заведующей отделом археологии СГМЗ С.Л. Кравцовой за консультацию по особенностям работы Т.М. Минаевой.

3 Дл - длина, Д - диаметр, Ш - ширина, Т толщина, В - высота.

\section{СПИСОК ЛИТЕРАТУРЫ}

1. Бандривский, М. С. Еще раз об овальных кольцах начала эпохи железа и об их функциональном назначении / М. С. Бандривский // Историкоархеологический альманах. Вып. 10. - Армавир ; Краснодар ; М. : ИА РАН, 2011. - С. 4-14.

2. Вальчак, С. Б. Предскифские колесницы и «новочеркасские клады» (некоторые дополнения к проблеме) / С. Б. Вальчак // Памятники предскифского и скифского времени на юге Восточной Европы. Материалы и исследования по археологии России. - М. : ИА РАН, 1997. - С. 40-56.

3. Вальчак, С. Б. Конское снаряжение в первой трети І-го тыс. до н.э. на юге Восточной Европы / С. Б. Вальчак. - М. : Таус, 2009. - 375 с.

4. Вальчак, С. Б. Уникальный «переднеазиатский» наконечник стрелы из Восточной Европы / С. Б. Вальчак // Историко-археологический альманах. Вып. 10. - Армавир ; Краснодар ; М. : ИА РАН, 2011.- C. 31-37.

5. Галанина, Л. К. Келермесские курганы. «Царские» погребения раннескифской эпохи / Л. К. Галанина. - М. : Центр сравнительного изучения древних цивилизаций Института всеобщей истории РАН, 1996. - 269 с.

6. Дударев, С. Л. Взаимоотношения племен Северного Кавказа с кочевниками Юго-Восточной Европы в предскифскую эпоху (IX - первая половина VII в. до н. э.) / С. Л. Дударев. - Армавир : Армавирское полиграфпредприятие, $1999 .-400$ с.

7. Есаян, С. А. Скифские памятники Закавказья / С. А. Есаян, М. Н. Погребова. - М. : Наука, 1985. $-287 \mathrm{c}$

8. Иванчик, А. И. Киммерийцы и скифы. Культурно-исторические и хронологические проблемы археологии восточноевропейских степей и Кавказа пред- и раннескифского времени / А. И. Иванчик. М. : Центр сравнительного изучения древних цивилизаций Института всеобщей истории РАН, 2001. $324 \mathrm{c}$.

9. Ильинская, В. А. Скифия VII - V вв. до н.э. / В. А. Ильинская, А. И. Тереножкин. - Киев : Наукова думка, 1987. -348 с.
10. Ковпаненко, Г. Т. Погребение воина у с. Квитки в Поросье / Г. Т. Ковпаненко, Н. Д. Гупало // Вооружение скифов и сарматов. - Киев : Наукова думка, 1984. - С. 42-56.

11. Козенкова, В. И. Оружие, воинское и конское снаряжение племен кобанской культуры (систематизация и хронология). Западный вариант / В. И. Козенкова. - М. : Наука, 1995. - 162 с.

12. Кудрявцев, А. А. Итоги изучения кургана № 2 могильника № 2 Татарского городища / А. А. Кудрявцев, Ю. А. Прокопенко, В. Н. Черкасов // Северный Кавказ и кочевой мир степей Евразии: VI «Минаевские чтения» по археологии, этнографии и краеведению Северного Кавказа : тез. докл. межрегион. науч. конф. (24-26 апр. 2003 г.). - Ставрополь : Изд-во СГУ, 2003. - С. 18-32.

13. Махортых, С. В. Скифы на Северном Кавказе / С. В. Махортых. - Киев : Наукова думка, 1991. $133 \mathrm{c}$.

14. Медведская, И. Н. Конский убор из могильника Сиалк В / И. Н. Медведская // Iranica Antiqua. 1983. - № 18. - С. 59-79.

15. Мелентьев, А. Н. Некоторые детали конской упряжи киммерийского времени (Аксайский клад) / А. Н. Мелентьев // Краткие сообщения Института археологии. Вып. 112. - М. : Наука, 1967. C. 42-44.

16. Мелюкова, А. И. Вооружение скифов / А. И. Мелюкова. - М. : Наука, 1964. -465 с. -(САИ ; Д1-4).

17. Минаева, Т. М. Археологические материалы скифского времени в Ставропольском краевом музее / Т. М. Минаева // Материалы по изучению Ставропольского края. Вып. 8. - Ставрополь : Ставропольское книжное издательство, 1956. - С. 337-356.

18. Петренко, В. Г. Изображение богини Иштар из кургана в Ставрополье / В. Г. Петренко // Краткие сообщения Института археологии. Вып. 162. - М. : Наука, 1980. - С. 38-54.

19. Петренко, В. Г. Краснознаменский могильник. Элитные курганы раннескифской эпохи на Северном Кавказе / В. Г. Петренко. - М. ; Берлин ; Бордо : Палеограф, 2006. - 175 c.

20. Рябкова, Т. В. Курган 524 у с. Жаботин в системе памятников скифской архаики / Т. В. Рябкова // Российский археологический вестник. 2014. - № 4. - С. 372-432.

21. Рудницкий, Р. Р. Колесничная упряжь новочеркасской эпохи из Железноводска / Р. Р. Рудницкий, В. А. Фоменко // Из истории народов Северного Кавказа. Вып. 1. - Ставрополь : Изд-во СГУ, 1997. C. 7-9.

22. Сазонов, А. А. Хаджохские курганы - некрополь древнемеотских вождей / А. А. Сазонов // Информационно-аналитический вестник. - Майкоп : Изд-во АРИГИ им. Т.М. Керашева, 2000. - С. 42-67. 
23. Скаков, А. Ю. О хронологии «киммерийских» и раннескифских древностей / А. Ю. Скаков, В. Р. Эрлих // Древности Евразии: от ранней бронзы до раннего средневековья : сб. ст. памяти В.С. Ольховского. - М. : ИАРАН, 2005. - С. 201-227.

24. Скорый, С. А. Киммерийцы в Украинской лесостепи / С. А. Скорый. - Киев ; Полтава : Издат. центр «Археология», 1999. - 356 с.

25. Степи европейской части СССР в скифосарматское время. - М. : Наука, 1986. - 463 с.

26. Тихонов, В. В. Новый комплекс киммерийского времени из Саратовской области / В. В. Тихонов // Взаимодействие и развитие древних культур южного пограничья Европы и Азии : материалы Междунар. науч. конф., посвящ. 100-летию со дня рождения И. В. Синицына (1900-1972), Саратов Энгельс, 14-18 мая 2000 г. - Саратов : Изд-во СГУ, 2000. - C. 149-150.

27. Эрлих, В. Р. Курган Уашхиту и проблема интерпретации некоторых комплексов типа Новочеркасского клада / В. Р. Эрлих // XVI «Крупновские чтения» по археологии Северного Кавказа. - Ставрополь : Изд-во СГПИ, 1990. - С. 59-60.

28. Эрлих, В. Р. У истоков раннескифского комплекса / В. Р. Эрлих. - М. : Изд-во Гос. музея Востока, 1994. - 145 с.

29. Эрлих, В. Р. Северо-Западный Кавказ в начале железного века. Протомеотская группа памятников / В. Р. Эрлих. - М. : Наука, 2007. - 678 с.

30. Эрлих, В. Р. К дискуссии о скифах на Кубани-2: обсуждение новых материалов и гипотез / В. Р. Эрлих // Пятая Кубанская археологическая конференция : материалы конференции. - Краснодар : Изд-во КГУ, 2009. - С. 453-454.

\section{REFERENCES}

1. Bandrivskiy M.S. Eshche raz ob ovalnykh koltsakh nachala epokhi zheleza i ob ikh funktsionalnom naznachenii [Once Again on the Oval Rings of the Beginning of the Iron Age and on Their Functional Purpose]. Istoriko-arkheologicheskiy almanakh. Vyp. 10 [Historical and Archaeological Almanac. Iss. 10]. Armavir; Krasnodar; Moscow, IA RAN Publ., 2011, pp. 4-14.

2. Walczak S.B. Predskifskie kolesnitsy i «novocherkasskie klady» (nekotorye dopolneniya k probleme) [Scythian Chariots and "Novocherkassk Hoards" (Some Additions to the Problem)]. Pamyatniki predskifskogo i skifskogo vremeni na yuge Vostochnoy Evropy. Materialy $i$ issledovaniya po arkheologii Rossii [Monuments of Pre-Scythian and Scythian Period in the South East Europe. Materials and Research on Russian Archaeology]. Moscow, IA RAN Publ., 1997, pp. 40-56.
3. Walczak S.B. Konskoe snaryazhenie v pervoy treti I-go tys. do n.e. na yuge Vostochnoy Evropy [Caparison in the First Third of the $1^{\text {st }}$ Millennium BC in the South-Eastern Europe]. Moscow, Taus Publ., 2009. $375 \mathrm{p}$.

4. Walczak S.B. Unikalnyy «peredneaziatskiy» nakonechnik strely iz Vostochnoy Evropy [Unique Persian Arrowhead from Eastern Europe]. Istorikoarkheologicheskiy almanakh. Vyp. 10 [Historical and Archaeological Almanac. Iss. 10]. Armavir; Krasnodar; Moscow, IA RAN Publ., 2011, pp. 31-37.

5. Galanina L.K. Kelermesskie kurgany. "Tsarskie» pogrebeniya ranneskifskoy epokhi [Kelermess Barrows. "Royal" Burials of Early Scythian Epoch]. Moscow, Tsentr sravnitelnogo izucheniya drevnikh tsivilizatsiy Instituta vseobshchey istorii RAN, 1996. 269 p.

6. Dudarev S.L. Vzaimootnosheniya plemen Severnogo Kavkaza s kochevnikami YugoVostochnoy Evropy v predskifskuyu epokhu (IX pervaya polovina VII v. do n.e.) [Relationships of Tribes of the North Caucasus with the Nomads of South-Eastern Europe in the Pre-Scythian Epoch $\left(9^{\text {th }}-\right.$ First Half of the $7^{\text {th }}$ Century BC)]. Armavir, GUP “Armavirskoe poligrafpredpriyatie” Publ., 1999.400 p.

7. Esayan S.A., Pogrebova M.N. Skifskie pamyatniki Zakavkazya [Scythian Monuments of Transcaucasia]. Moscow, Nauka Publ., 1985. 287 p.

8. Ivanchik A.I. Kimmeriytsy i skify. Kulturnoistoricheskie $i$ khronologicheskie problemy arkheologii vostochnoevropeyskikh stepey i Kavkaza pred- $i$ ranneskifskogo vremeni [Cimmerians and Scythians. Cultural, Historical and Chronological Problems of Archaeology of Eastern European Steppes and the Caucasus in Pre- and Early Scythian Time]. Moscow, Tsentr sravnitelnogo izucheniya drevnikh tsivilizatsiy Instituta vseobshchey istorii RAN, 2001. $324 \mathrm{p}$.

9. Ilyinskaya V.A., Terenozhkin A.I. Skifiya VII$V v v$. do n.e. [Scythia of the $7^{\text {th }}-5^{\text {th }}$ cc. BC]. Kiev, Naukova dumka Publ., 1987. 348 p.

10. Kovpanenko G.T., Gupalo N.D. Pogrebenie voina u s. Kvitki v Porosye [Warrior Burial at Kvitki Village in Porosye]. Vooruzhenie skifov i sarmatov [Armament of the Scythians and Sarmatians]. Kiev, Naukova dumka Publ., 1984, pp. 42-56.

11. Kozenkova V.I. Oruzhie, voinskoe i konskoe snaryazhenie plemen kobanskoy kultury (sistematizatsiya i khronologiya). Zapadnyy variant [Weapons, Military and Horse Equipment of Koban Tribes (System and Chronology). Western Version]. Moscow, Nauka Publ., 1995. 162 p.

12. Kudryavtsev A.A., Prokopenko Yu.A., Cherkasov V.N. Itogi izucheniya kurgana № 2 mogilnika № 2 Tatarskogo gorodishcha [Results of the Study of Barrow 2 of Burial Mound 2 of the Tatar Settlement]. 
Severnyy Kavkaz i kochevoy mir stepey Evrazii: VI «Minaevskie chteniya» po arkheologii, etnografii $i$ kraevedeniyu Severnogo Kavkaza. Tezisy dokladov mezhregionalnoy nauchnoy konferentsii (24-26 apr. 2003 g.) [The North Caucasus and the Nomadic World of Eurasian Steppes: $6^{\text {th }}$ Minaev's Readings on Archaeology, Ethnography and Local History of the North Caucasus. Abstracts of Interregional Scientific Conference (April 24-26, 2003)]. Stavropol, Izd-vo SGU, 2003, pp. 18-32.

13. Makhortykh S.V. Skify na Severnom Kavkaze [Scythians in the North Caucasus]. Kiev, Naukova dumka Publ., 1991. 133 p.

14. Medvedskaya I.N. Konskiy ubor iz mogilnika Sialk V [Horse Harness from Burial Mound in Sialk 5]. Iranica Antiqua, 1983, no. 18, pp. 59-79.

15. Melentyev A.N. Nekotorye detali konskoy upryazhi kimmeriyskogo vremeni (Aksayskiy klad) [Some parts of harness Cimmerian time (Aksai treasure)]. Kratkie soobshcheniya Instituta arkheologii. Vyp. 112 [Brief Reports of the Institute of Archaeology. Iss. 112]. Moscow, Nauka Publ., 1967, pp. 42-44.

16. Melyukova A.I. Vooruzhenie skifov [Scythians' Armament]. Svod arkheologicheskikh istochnikov [Collected Archaeological Sources]. Moscow, Nauka Publ., 1964. 465 p.

17. Minaeva T.M. Arkheologicheskie materialy skifskogo vremeni v Stavropolskom kraevom muzee [Archaeological Materials of Scythian Time in the Stavropol Regional Museum]. Materialy po izucheniyu Stavropolskogo kraya. Vyp. 8 [Materials for the Study of the Stavropol Krai. Iss. 8]. Stavropol, Stavropolskoe knizhnoe izd-vo, 1956, pp. 337-356.

18. Petrenko V.G. Izobrazhenie bogini Ishtar iz kurgana v Stavropolye [The Image of Goddess Ishtar from the Barrow in the Stavropol Region]. Kratkie soobshcheniya Instituta arkheologii. Vyp. 162 [Brief Reports of the Institute of Archaeology. Iss. 162]. Moscow, Nauka Publ., 1967, pp. 38-54.

19. Petrenko V.G. Krasnoznamenskiy mogilnik. Elitnye kurgany ranneskifskoy epokhi na Severnom Kavkaze [Krasnoznamensky Burial Mound. Elite Barrows of Early Scythian Epoch in the North Caucasus]. Moscow; Berlin; Bordo, Paleograf Publ., 2006. 175 p.

20. Ryabkova T.V. Kurgan 524 u s. Zhabotin v sisteme pamyatnikov skifskoy arkhaiki [Barrow 524 near the Village of Zhabotin in the System of Scythian Archaic Monuments]. Rossiyskiy arkheologicheskiy vestnik, 2014, no. 4, pp. 372-432.

21. Rudnitskiy R.R., Fomenko V.A. Kolesnichnaya upryazh novocherkasskoy epokhi iz Zheleznovodska [Chariot Harness from Zheleznovodsk of the Novocherkassk Epoch]. Iz istorii narodov Severnogo
Kavkaza. Vyp. 1 [From the History of the North Caucasus's Peoples. Iss. 1]. Stavropol, Izd-vo SGU, 1997, pp. 7-9.

22. Sazonov A.A. Khadzhokhskie kurgany nekropol drevnemeotskikh vozhdey [Khadzhokh Barrows - Necropolis of the Ancient Meotian Leaders]. Informatsionno-analiticheskiy vestnik [Information-Analytical Bulletin]. Maikop, Izd-vo ARIGI im. T.M. Kerasheva, 2000, pp. 42-67.

23. Skakov A.Y., Erlikh V.R. O khronologii «kimmeriyskikh» i ranneskifskikh drevnostey [About the Chronology of Cimmerian and Early Scythian Antiquities]. Drevnosti Evrazii: ot ranney bronzy do rannego srednevekovya: sb. st. pamyati V.S. Olkhovskogo [Antiquities of Eurasia: from the Early Bronze Age to the early Middle Ages. Collected Papers in Memory of V.S. Olkhovsky]. Moscow, IA RAN Publ., 2005, pp. 201-227.

24. Skory S.A. Kimmeriytsy v Ukrainskoy lesostepi [Cimmerians in the Ukrainian Steppe]. Kiev; Poltava, Arkheologiya Publ., 1999. 356 p.

25. Stepi evropeyskoy chasti SSSR v skifosarmatskoe vremya [Steppes of the European Part of the USSR in the Scythian-Sarmatian Time]. Moscow, Nauka Publ., 1986. 463 p.

26. Tikhonov V.V. Novyy kompleks kimmeriyskogo vremeni iz Saratovskoy oblasti [The new complex of the Cimmerian time of the Saratov region]. Vzaimodeystvie i razvitie drevnikh kultur yuzhnogo pogranichya Evropy i Azii: materialy Mezhdunar. nauch. konf., posvyash. 100-letiyu so dnya rozhdeniya I.V. Sinitsyna (1900-1972), Saratov - Engels, 1418 maya $2000 \mathrm{~g}$. [Interaction and Development of Ancient Cultures of the Southern Borderlands of Europe and Asia. Materials of the International Academic Conference Dedicated to the $100^{\text {th }}$ Birth Anniversary of I.V. Sinitsyn (1900-1972), Saratov Engels, May 14-18, 2000]. Saratov, Izd-vo SGU, 2000, pp. $149-150$.

27. Ehrlich V.R. Kurgan Uashkhitu i problema interpretatsii nekotorykh kompleksov tipa Novocherkasskogo klada [Uashkhitu Barrow and the Problem of Interpretation of Some Complexes of Novocherkassk Hoard]. XVI «Krupnovskie chteniya» po arkheologii Severnogo Kavkaza [The $16^{\text {th }}$ Krupnov's Readings on the Archaeology of the North Caucasus]. Stavropol, Izd-vo SGPI, 1990, pp. 59-60.

28. Ehrlich V.R. U istokov ranneskifskogo kompleksa [At the Root of the Early Scythian Complex]. Moscow, Izd-vo Gos. muzeya Vostoka, 1994. $145 \mathrm{p}$.

29. Erlikh V.R. Severo-Zapadnyy Kavkaz v nachale zheleznogo veka. Protomeotskaya gruppa pamyatnikov [Northwest Caucasus in the Early Iron Age. Protomeotian Group of Monuments]. Moscow, Nauka Publ., 2007. 678 p. 
Ю.А. Прокопенко. Комплекс предметов вооружения и конской упряжи раннескифской культуры

30. Erlikh V.R. K diskussii o skifah na Kubani-2: obsuzhdenie novykh materialov i gipotez [Discussion of the Scythians in the Kuban-2: Discussion of New Materials and Hypotheses]. Pyataya Kubanskaya arkheologicheskaya konferentsiya: materialy konferentsii [Fifth Kuban archaeological conference. Conference proceedings]. Krasnodar, KGUPubl., 2009, pp. 453-454.

\section{Information about the Author}

Yuriy A. Prokopenko, Doctor of Sciences (History), Associate Professor, Professor of Department of Cultural Studies and Arts, North-Caucasus Federal University, Pushkina St., 1, 355009 Stavropol, Russian Federation, z_proko_15@mail.ru, https:/orcid.org/0000-0001-7060-5054

\section{Информация об авторе}

Юрий Анатольевич Прокопенко, доктор исторических наук, доцент, профессор кафедры социальной философии и этнологии, Северо-Кавказский федеральный университет, ул. Пушкина, 1 , 355009 г. Ставрополь, Российская Федерация, z_proko_15@mail.ru, https://orcid.org/0000-0001-7060-5054 